\title{
The Jubilee of PaedDr. Mária Uhereková, PhD.
}

\author{
Viola Tamášová - Silvia Barnová*
}

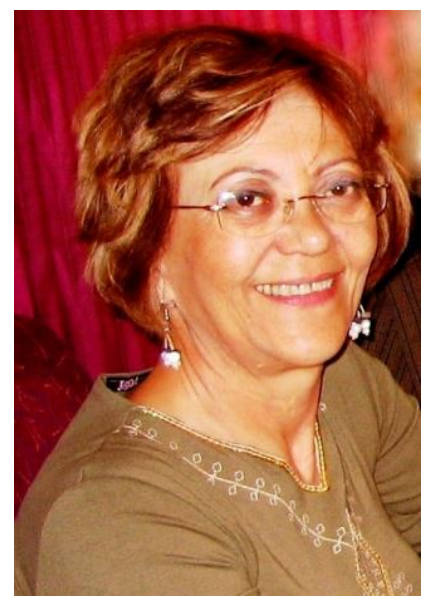

PaedDr. Mária Uhereková, PhD., a distinguished representative of Slovak pedagogy, will celebrate her life anniversary in September. She was born 28 September 1946 in Hrachovo, a picturesque village near Rimavská Sobota.

She started her professional career in 1969 after finishing her university studies at the Faculty of Education of Comenius University in Bratislava located in Trnava. She studied teacher training in the fields of Biology and Chemistry.

First, she worked as a specialist at the department of creation of didactic tests in the institution called Psychodiagnostické a didaktické testy (Psychodiagnostic and didactic tests) in Bratislava. Then, she started teaching her teaching subjects

Viola Tamášová, Dubnica Institute of Technology in Dubnica nad Váhom, Dubnica nad Váhom, Slovakia; tamasova@dti.sk

Silvia Barnová, Dubnica Institute of Technology in Dubnica nad Váhom, Dubnica nad Váhom, Slovakia; barnova@dti.sk 


\section{Acta Technologica Dubnicae \\ volume 6, 2016, issue 2}

at primary schools, e.g. in Vysoká na Morave and in several schools in Bratislava (Duklianska ul., Nevädzová ul., Ul. Š. Majora, Cádrová ul., Ul. E. Thälmanna). At some of the schools, she was the head of the department of biology, she was employed as a lecturer at the Faculty of Natural Sciences of Comenius University and was also a methodician of biology. Later, she worked as a school inspector for natural sciences at the Inspection Centre in Bratislava, as the chief school inspector at the Inspection Centre Bratislava I - V and as the head of the department of elementary schools and kindergartens. From this position, she moved to State Pedagogical Institute in Bratislava and became a didactitian of biology. As she gained rich experiences in the fields of teaching at elementary schools, methodics, subject didactics and from school management, it is natural that she became a school inspector and the director of the department of school inspection at the Ministry of Education of the Slovak Republic in Bratislava. From this high position she moved to State School Inspection in Bratislava and worked as a school inspector for elementary schools. Her professional and personal qualities were really needed and she took up the position of the deputy chief school inspector (till 2007).

Between the stages of her career, Dr. Mária Uhereková expanded her qualifications - from post-gradual studies, attending professional courses, courses of school management, to earning the academic degree of Doctor of Pedagogy (PaedDr.) in 2001 at the Faculty of Natural Sciences of Comenius University in Bratislava and the highest academic degree Philosophiae Doctor (PhD.) in the field of pedagogy at the Faculty of Education of Comenius University in Bratislava in 2007. The same year, she changed her employment and started lecturing (until 2011) at Comenius University in Bratislava, Department of Pedagogy of the Faculty of Education as an assistant professor. She specialised herself in school management, school legislation and documentation, as well as drug abuse prevention. In these scientific fields, she has published many studies, scholarly articles, handbooks for teachers, taken part in various project and contributed to many scientific conferences. Since 2011, she has worked as a university teacher at a private institution, Dubnica Institute of Technology in Dubnica nad Váhom. She is an excellent teacher, students have characterized her as an excellent, bright and tolerant teacher with a human approach to her students. She has supervised many Bachelor and Master theses of a high level and her themes belong to the most topical and interesting ones.

Dr. Uhereková has taken part in many KEGA and VEGA grant projects of the Ministry of Education of the Slovak Republic as a member of research teams and, since 2009, she has contributed to the work on the national project External Evaluation of the Quality of Schools Supporting Self-Evaluation Processes in Schools to a great extent. She focuses on the importance of self-evaluation 


\section{Acta Technologica Dubnicae \\ volume 6, 2016, issue 2}

processes in schools and on the need for an active use of quality criteria and the instruments of self-evaluation in the process of evaluating the individual modules that were created and verified in practice by her. She aimes to show some new methods and forms of work of external evaluation of schools to the professionals at State School Inspection and, at the same time, to create, in cooperation with professionals from the field of pedagogy, instruments for internal evaluation of schools. All her effort and the purpose of the project is to increase the quality and the level of provided education in accordance with the European trends. For her, the quality of education is one of the most important educational requirements.

She has reflected her love to biology in the textbooks for elementary and secondary schools she has created (in co-authorship). Among them are: Biology for the 8th Grade of Elementary schools (Prírodopis pre 8. ročník základných škôl, 2006), Biology and Health Care for the 1st Grade of the Field of Study Social Educational Worker (Biológia a starostlivost' o zdravie pre 1. ročník študijného odboru sociálno-výchovný pracovník, 2006), Biology - Organisms and Ecosystems (Biológia - organizmy a ekosystémy, 2010), Biology and Health Care (Biológia a starostlivost' o zdravie, 2007, 2014), Biology (Biológia, 2010), Biology for the 5th, 7th and 8th Grade of Elementary Schools (Biológia pre 5., 7., 8. ročník základnej školy, 2009, 2011, 2012, 2014), in Hungarian mutation Biology for the 7th Grade of Elementary Schools and the 2nd Grade of 8-Year Grammar Schools (Biológia az alapiskolák 7. és a nyolcosztályos gimnázium 2. évfolyama számára, 2012), Biology for the 5th Grade of Elementary schools (Biológia az alapiskolák 5. évfolyama számára, 2012), Biology - Life of Organisms and Hygiene of Environment (Biológia - život organizmov a hygiena prostredia, 2014). These are colourful, beautiful and creatively prepared textbooks with a high quality content taking into account the didactic aspect. It is a pleasure to teach from them!

Recently, she has been working on big project of Dr. Josef Raabe publishing house, Slovakia - on the creation of Methodical Handbook for Biology for the $5^{\text {th }}$ Grade of Elementary Schools (Metodická príručka k učebnici Biológie pre 5. ročník základnej školy) and Didactic Introduction to the Current Trends in Teaching Biology (Didaktický úvod k súčasným trendom vyučovania biológie). It fills her with energy and enthusiasm.

Dear Dr. Mária Uhereková, a precious friend and colleague, always decent, active, helpful, punctual, intelligent, non-confrontational, but ready to fight for the truth. In our name and on behalf of the Editorial Board of Acta Technologica Dubnicae, we wish you a lot of creative energy, good prosperity, a lot of love from your dearests, pleasant professional meetings and friendly meetings with those who like you. 